\title{
眼輪筋皮弁による眼瞼周囲腫瘍切除後皮膚欠損の再建
}

\author{
中村 泰大 許 雪珠 高橋 毅法 大塚 藤男 \\ 筑波大学大学院人間総合科学研究科病態制御医学専攻皮庙病態医学分野
}

\begin{abstract}
要旨 症例 $1 ; 13$ 歳男児。生下時より右下眼瞼の茶褐色斑があり, 最近整容的に気になり受診。 初診時右下眼瞼外側に $15 \times 12 \mathrm{~mm}$ の茶褐色斑あり。辺縁より $1 \mathrm{~mm}$ 離して切除。病理組織学 的に扁平母斑と診断。

症例 $2 ; 80$ 歳男性。数年前より, 左上眼瞼の黒色結節を自覚。近医での生検で基底細胞癌の 診断。初診時 $7 \times 5 \mathrm{~mm}$ の黑色結節あり。辺縁より $2 \mathrm{~mm}$ 離して切除。

症例 $3 ; 72$ 歳男性。数年前より右下眼瞼の黒褐色結節に気付く。徐々に増大してきたため受 診。初診時 $12 \times 10 \mathrm{~mm}$ の黒褐色結節あり。病理組織学的に基底細胞癌と診断。辺縁より $2 \mathrm{~mm}$ 離して切除。

3 例共に切除後の皮膚欠損を眼輪筋皮弁で再建した。本皮弁は豊富な血流で栄養される眼輪 筋を皮下茎とするため, 皮弁の血行は安定しており, 移動も容易である。眼瞼周囲の皮膚欠損 に対し外来手術で行える簡便かつ有用な再建法であると考える。
\end{abstract}

\section{Orbicularis oculi musculocutaneous flap for reconstruction of skin defects of the orbital region after tumor excision}

Yasuhiro NAKAMURA, Xuezhu XU, Takenori TAKAHASHI, Fujio OTSUKA

Department of Dermatology, Graduate School of Comprehensive Human Sciences Medical Sciences for Control of Pathological Processes, University of Tsukuba

We report three reconstructive cases of periocular skin defects after tumor excision with orbicularis oculi musculocutaneous flap (OOMCF). (Case 1) A 13-year-old male presented with a $15 \times 12 \mathrm{~mm}$ brown macule on his right lower eyelid. Histological examination showed nevus spilus. (Case 2) An 80year-old man had a $7 \times 5 \mathrm{~mm}$ black-brown tumor on his left upper eyelid. Histological examination revealed basal cell carcinoma. (Case 3) A 72-year-old man developed a $12 \times 10 \mathrm{~mm}$ black-brown tumor on his right lower eyelid. Histological examination showed basal cell carcinoma. All 3 cases were reconstructed by OOMCF. Because the pedicle of this flap is only orbicularis oculi muscle, which is well vasculized from small branches of the internal or external carotid artery, this flap can be raised very safely and easily, and has good mobility. OOMCF is very useful for the reconstruction of skin defects of the orbital region. [Skin Cancer (Japan) 2006 ; $21: 215-219$ ]

Key words : Orbicularis oculi musculocutaneous flap (OOMCF). V-Y advancement flap, Eyelid 


\section{はじめに}

眼瞼周囲における腫瘍切除後の皮膚欠損の再 建は視機能および外見へ配慮が必要である。再 建には現在植皮や数々の皮弁が用いられてい る。今回我々は眼輪筋皮弁 (orbicularis oculi musclocutaneous flap：以下 OOMCF）による 再建を 3 例経験したので報告し，本皮弁の利 点・欠点について考察する。

\section{症例}

\section{症例 1}

患 者: 13 歳, 男児

初 診: 2006 年 1 月 26 日

現病歴：生下時より右下眼瞼に茶褐色斑が
あった。最近整容的に気になってきたため，当 科を受診した。

初診時現症：右下眼瞼外側に $15 \times 12 \mathrm{~mm}$ の 有毛性の茶褐色斑がある。

病理組織学的所見: 切除後の病理組織は表皮 基底層にメラニン顆粒が多数みられる扁平母斑 の病理組織像であった。

治療と経過：臨床所見より扁平母玟と診断し た。Q-スイッチアレキサンドライトレーザー による治療を勧めたが，切除を希望されたた め, 色素斑辺縁より $1 \mathrm{~mm}$ 離して脂肪層浅層で 切除した。欠損部外側にOOMCFとして眼輪 筋を茎とする V-Y advancement flap を作成し (図 $1 \mathrm{a}$ )，欠損部に前進移動して再建した（図 $1 \mathrm{~b}, \mathrm{c}$ )。術後 1 力月で眼瞼の外反はない（図 $1 \mathrm{~d})$ 。
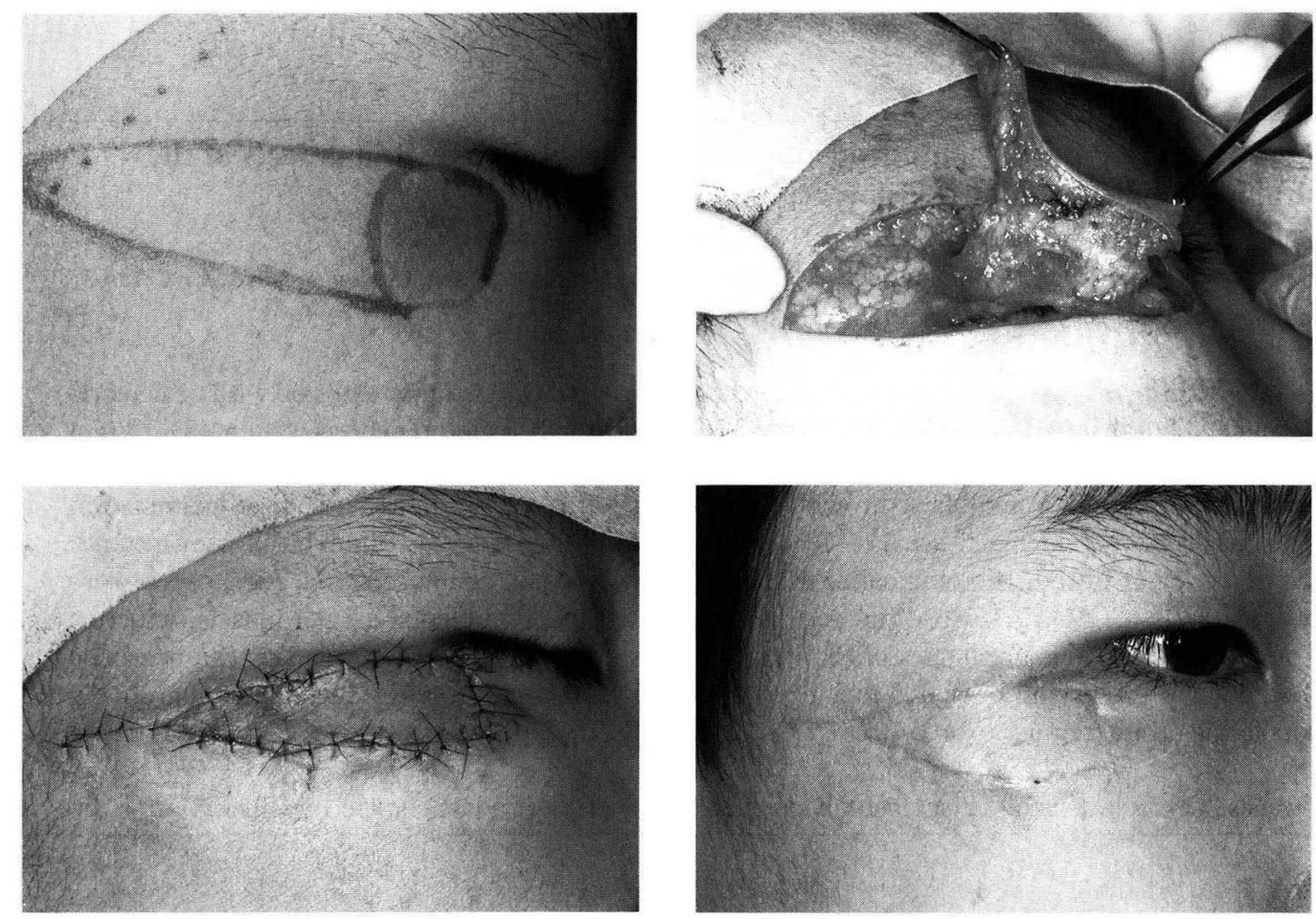

\begin{tabular}{l|l}
$\mathrm{a}$ & $\mathrm{b}$ \\
\hline $\mathrm{c}$ & $\mathrm{d}$
\end{tabular}

図 1. a. 症例 1 の皮弁デザイン（点線は顔面神経側頭枝の走行部位）

b. 皮弁挙上

c. 手術直後

d. 術後 1 力月の臨床像 
症例 2

患 者：80 歳, 男性

初 診: 2002 年 7 月 25 日

現病歴: 数年前より, 左上眼瞼の黒褐色結節 に気付く。徐々に増大してきたため, 近医受診。 部分生検で基底細胞癌と診断され, 拡大切除目 的で当科を紹介受診した。

初診時現症: 左上眼瞼に $7 \times 5 \mathrm{~mm}$ の黑褐色 結節がある。

病理組織学的所見：前医での生検標本および 切除後の病理組織は, 表皮基底層から真皮中層 にわたり，基底細胞様細胞が島状に増殖する基 底細胞癌の病理組織像であった。

治療と経過：腫瘍辺縁より $2 \mathrm{~mm}$ 離して眼輪 筋上で切除した。欠損部外側に OOMCFとし て眼輪筋を菱とする V-Y advancement flapを 作成し（図２ａ）, 欠損部に前進移動して再建
した（図 2 b, c)。術後 3 年で腫瘍の再発はなく, 両眼瞼の形態は左右対称で眼瞼外反もない（図 2 d)。

症例 3

患 者: 72 歳, 男性

初 診: 2005 年 4 月 14 日

現病歴：数年前より, 右下眼瞼の黑褐色結節 に気付く。徐々に増大してきたため当科を受診 した。

初診時現症：右下眼瞼に $12 \times 10 \mathrm{~mm}$ の褐色 結節があり，その一部に黑色結節が点在する。

病理組織学的所見 : 切除後の病理組織は, 表 皮基底層から真皮中層にわたり, 基底細胞様細 胞が結節状に増殖する基底細胞癌の病理組織像 であった。

治療と経過：腫瘍辺縁より $2 \mathrm{~mm}$ 離して眼輪 筋上で切除した。欠損部外側下方に OOMCF
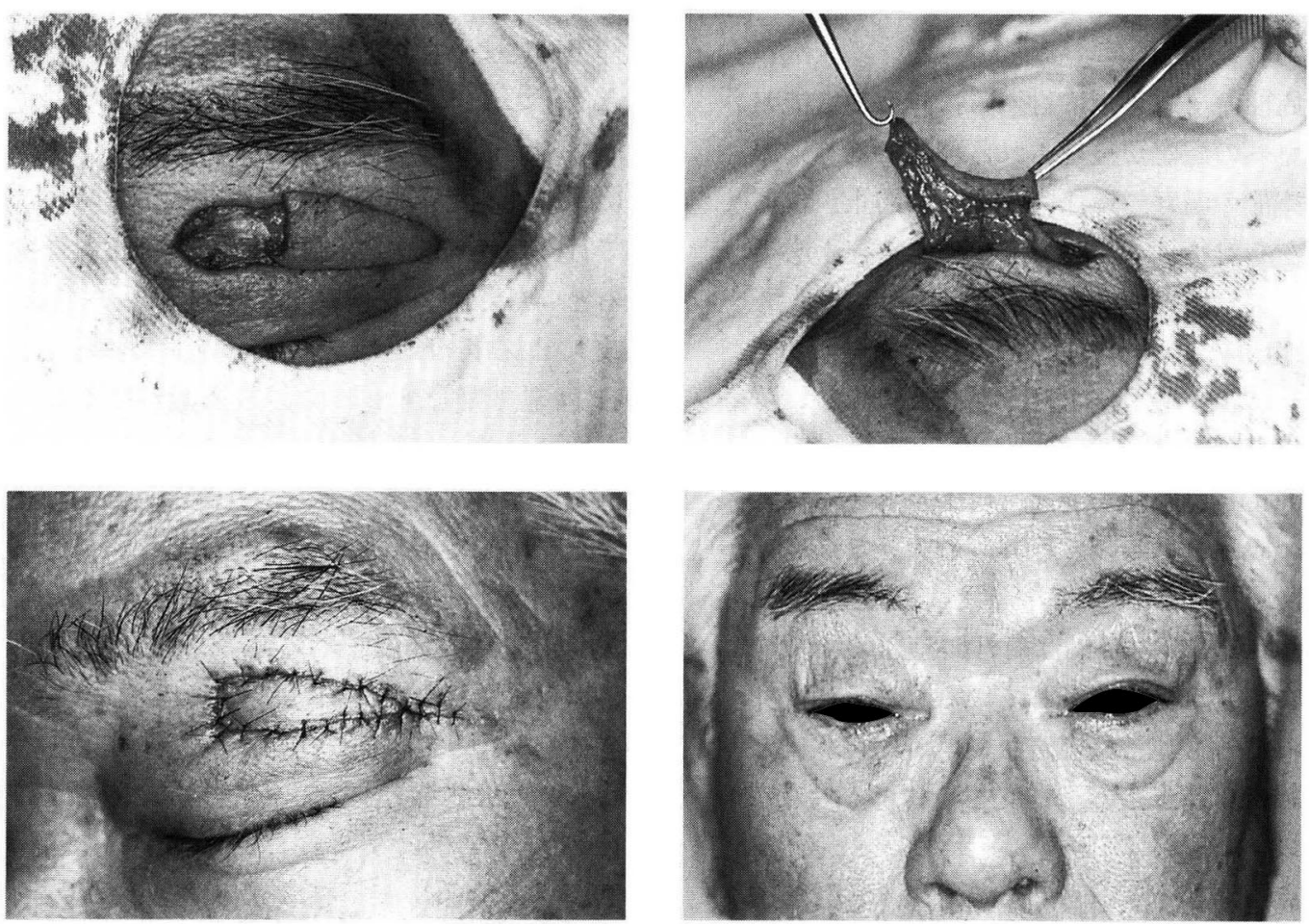

\begin{tabular}{l|l}
$\mathrm{a}$ & $\mathrm{b}$ \\
\hline $\mathrm{c}$ & $\mathrm{d}$
\end{tabular}

図2、a. 症例 2 の皮弁切開時（腫瘍は切除後）

b. 皮弁挙上（頭側より皮弁を見ている）

c. 手術直後

d. 術後 3 年の臨床像 

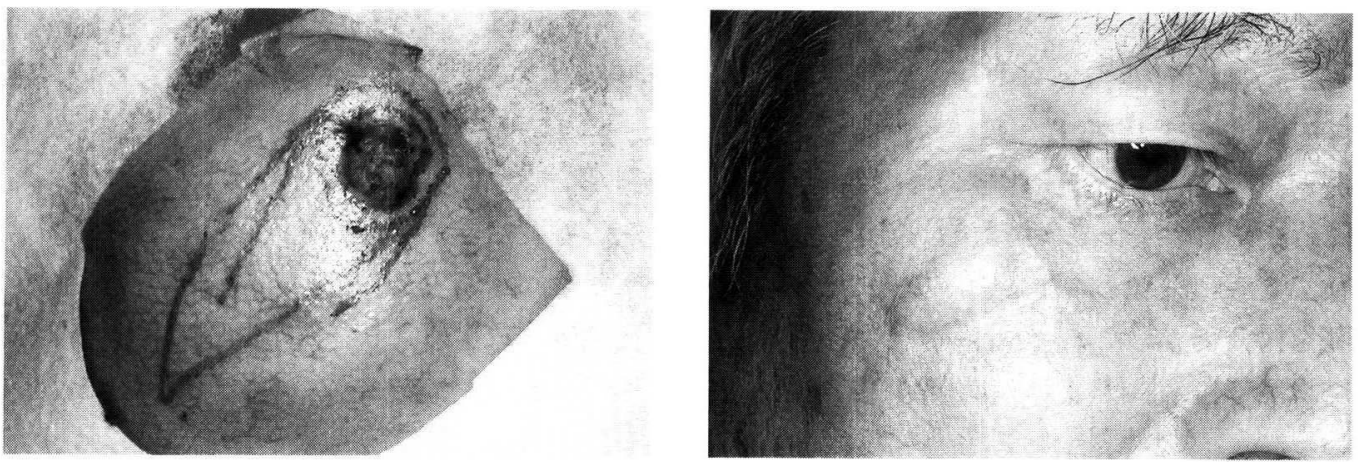

$\mathrm{a} \mid \mathrm{b}$

図 3. a. 症例 3 の皮弁デザイン

b. 術後 8 力月の臨床像

として眼輪筋を茎とする V-Y advancement flap を作成し（図 $3 a$ ), 久損部に移動して再建 した。術後 8 力月で腫瘍の再発はなく, 周囲皮 虐との color match も良好で眼瞼の外反もない (図 $3 b$ )。

\section{考察}

眼瞼周囲の皮虐欠損に対する再建は視機能お よび外見への配慮が重視される部位であり，眼 球運動機能の温存, 外反内反変形の防止, 位置 および左右対称性の再現を考慮した再建が必要 である。再建には植皮や lateral orbital flap ${ }^{12)}$, cheek rotation flap $^{3)}$, 前額側頭皮弁 ${ }^{4)}$, 前額正 中皮弁 ${ }^{4)}$ な゙の各種の皮弁が報告されている が，今回我々は $\mathrm{OOMCF}^{5) 6}$ による再建を行っ た。OOMCF は眼輪筋筋体を皮下茎とする皮弁 である。眼輪筋は眼裂を取り井む大きな筋肉で 眼瞼部と眼窩部に分かれ，最大直径は時に $8 \mathrm{~cm}$ 以上に及ぶ。筋体は内外頸動脈の多数の 分枝により豊富に栄養されているため，本皮弁 挙上時の血行も非常に安定している。自験例と 過去の報告を踏まえて，本皮弁の利点と欠点に ついて以下に考察する。

利 点：(1) V-Y advancement flap として挙 上するため dog ear が生じず縫合線の大部分が 㱀に一致し整容的に優れる，(2)茎を筋体のみに できるので皮弁の移動が容易である ${ }^{5)}$ ，(3)顔面
神経損傷の危険性が低い ${ }^{5)}$ ，(4)外来手術として 行える5)ことがあげられる。(2)については自験 例では眼輪筋下の剥離をさほど行わなくとも $1.5 \mathrm{~cm}$ 程度の皮并の移動は容易であったことか ら，茥を筋体のみにすれば $2 \mathrm{~cm}$ 以上の前進移 動が可能であると考える。(3については自験例 では神経刺激装置を用いずに手術したが，顔面 神経損傷による表情筋の麻痺はなかった。しか し症例 1 のように，顔面神経側頭枝の走行部位 が皮弁の作成部位と重なることがある。その際 には神経の走行部位付近での皮弁挙上を真皮浅 層で行うか, 神経刺激装置を用い神経損傷を避 けるといった配慮が必要である。(4)については, 植皮による再建では術後 $5 \sim 7$ 日程度の tie over 固定を要し，一時的閉眼処置が必要なこ ともあり，多くは入院が必要となる。一方，自 験例はいずれも外来手術で行ったが，強固な圧 迫固定や閉眼処置も必要なく，外来手術で行っ てもまったく問題なかった。

欠 点: 合併症として尾郷ら ${ }^{5)}$ は一時的合併 症 i ) 阻血性のうっ血 $(8 / 46: 17.4 \%)$, ii ) 浮 腫 $(5 / 46: 10.9 \%)$, iii ) 筋麻痺 $(2 / 46: 4.3 \%)$, また永久的合併症として，iv）皮弁膨隆および 皮弁の大きすぎによる整容的不満足（5/46： $10.9 \%)$ ，V）重瞼線不整（5/46：10.9\%）など がみられたとしている。i） ii ）については静 脈およびリンパ流の還流障害， iii）は筋支配神 経の損傷によるもので，皮弁挙上時の微小な血 
管，リンパ管，神経の損傷に起因している。ゆ えに血行が安定している皮弁であるとはいえ， これらの合併症を避けるために筋および筋周囲 の切離・剝離は必要以上に行わず, 皮弁移動が 無理なく行える最小限に留めるべきである。一 方で筋周囲の剝離が不十分だと，縫合時に眼瞼 に緊張がかかり容易に外反するため, バランス を配慮した剥離が必要である。自験例ではｉ） ii ） iii）は一切生じなかったが, 眼輪筋下をあ まり剥離せず皮弁が移動できたため，ここから 皮弁に流出入する微小血管, リンパ管, 神経が 温存されたためと考える。iv）v）は主に上眼 瞼で生じており，不適切な皮弁のデザインに起 因している。上眼瞼での本皮弁作成時には皮弁 の大きさ，作成位置を緻密に検討するべきであ る。

結論として, 直径 $2 \mathrm{~cm}$ 程度までの眼瞼周囲 の皮䖉欠損であれば，OOMCF は外来手術でで きる比較的簡便で整容的にも優れた有用な再建
法であると考える。

\section{文献}

1）小川 豊：Lateral orbital flap による義眼床再建. 形成外科, $41: 125-129,1998$

2 ）添田周吾: 皮下茎皮弁の応用。形成外科， 35 : 1353-1357, 1992

3 ) Jackson IT : Local flap reconstruction of defects after excision of nonmelanoma skin cancer. Clin Plast Surg, 24 : 747-767, 1997

4 ）酒井成身：上眼瞼の前葉再建：各種局所皮弁によ る顔面の再建最近の進歩. 波利井清紀, 小川 豊編, 第 1 版，克誠堂出版，2002，45-54

5）尾郷 賢：眼輪筋 MC 皮弁（OOMCF）による眼窩 周辺の皮虐再建術：各種局所皮弁による顔面の再 建最近の進歩. 波利井清紀, 小川 豊編, 第 1 版, 克誠堂出版, 2002, 1-9

6 ) Yoshimura $Y$, Nakajima $T$ : Reconstruction of the entire eyelid area with a subcutaneous pedicle based on orbicularis oculi muscle. Plast Reconstr Surg, 88: 136-139, 1991 